\title{
Comparative Anatomical and Histological Study of the pecten oculi in three species of birds that differ in their nutrition
}

\author{
Ameer Mahmood Taha Al-Hamdany Hamid Hassan Hamid AL-arajee \\ Department of biology / College of Education for pure Sciences \\ University of Mosul \\ amhamdany@gmail.com \\ alfahamhamid@gmail.com
}

DOI: $\underline{10.33899 / \text { edusj.2019.162972 }}$

Received

14 / $10 / 2018$
Accepted

03 / 12 / 2018

\begin{abstract}
The present study dealt with the anatomical and histological structure of pecten oculi in three species of birds that differ in their nutrition, these birds were Accipiter nisus, Sturnus vulgaris and Taeniopygia guttata, by using compound light microscope and five different histological stains. The result showed that, pecten oculi was in the three species of pleated type and consisted of 17 folds in Accipiter nisus, 26 folds in Sturnus vulgaris and 19 folds in Taeniopygia guttata, these folds were vary in their thickness, as they were thicker in Accipiter nisus than the other two species. The results also showed that the pecten oculi folds of the three species contains three types of blood vessels: large size, medium size and blood capillaries. The three types of vessels were differ in their diameter and their distribution between the folds of pecten oculi with in one speceis as well as they differ in the other three species. Pecten oculi also contains pigment cells as well as peripheral cells, it ends in the three birds speceis with a structure known as the bridge which is consist of connective tissue and dense pigment cells. The bridge is rich in blood vessels of different sizes. The present study concluded that the pecten oculi differ in components and anatomical features in different speceis of birds.
\end{abstract}

Key words: birds, eye, pecten oculi 
دراسة تشريحية ونسجية مقارنة للممشط العيني في ثلاثة انواع من الطيور مختلفة التغذية

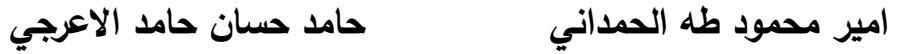

$$
\begin{aligned}
& \text { قسم علوم الحياة / كلية التربية للعلوم الصرفة }
\end{aligned}
$$

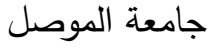

alfahamhamid@gmail.com

amhamdany@gmail.com

DOI: $10.33899 /$ edusj.2019.162972

القبول

الاستلام

2018 / 12 / 03

2018 / 10 / 14

المستخلص

تتاولت الدراسة الحالية التركيب التشريحي والنسجي للمشط العيني في ثلاثة انواع من الطيور مختلفة التغذية وهي باشق العصافير Accipiter nisus، الزرزور Sturnus vulgaris والعصفور المبرقش لـأشيه Taeniopygia guttata اظهرت النتائج ان الممشط في الانواع الثلاثة من النوع المطوي ويبلغ عدد طياته في الباشق (17) طية بينما في الزرزور بلغ عدد طياته (26) طية وبلغ عدد طياته في العصفور المبرقش (19) طية، وتتفاوت هذه الطيات بالسمك بين الانواع الثلاثة من الطيور فتكون اسمك في الباشق من النوعين الاخرين. كما بينت النتائج ان طيات

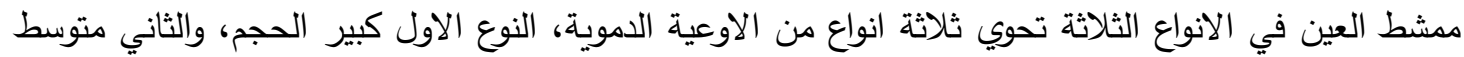
الحجم، اما النوع الثالث فهي الثعيرات الدموية وتختلف هذه الانواع الثلاثة من الاوعية في قطرها وتوزيعها بين

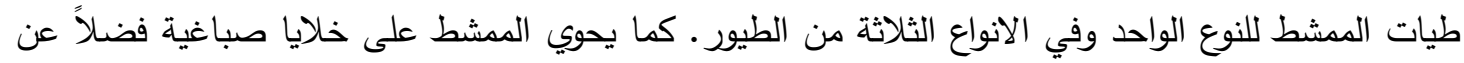
الخلايا المحيطية. وينتهي الممشط في الطيور الثلاثة بتركيب يعرف بالجسر والذي يتألف من نسيج ضلئ ضام وخلائيا

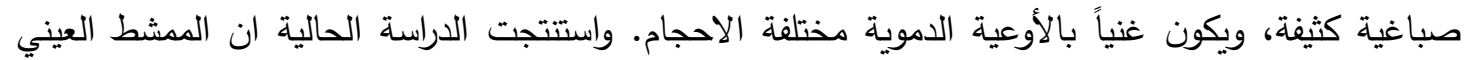
يختلف في مكوناته وصفاته التثريحية في الانواع المختلفة من الطيور •

الكلمات المفتاحية: الطيور، العين، المشط العيني

\section{Introduction المقدمة}

إن السمة الأكثر تميزاً في عيون الطيور هي وجود المشط العيني وهو تركيب صباغي متعدد الطيات

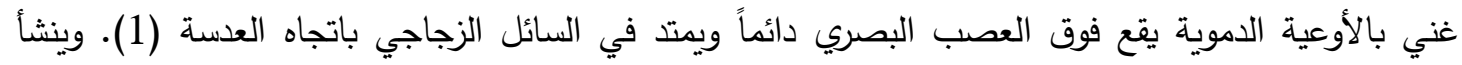
المشط من خلايا الأديم الظاهر العصبي المغطي للأديم المتوسط الوعائي (الأنسجة المشيمية) (2). يكون

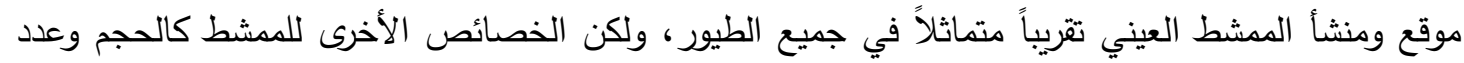

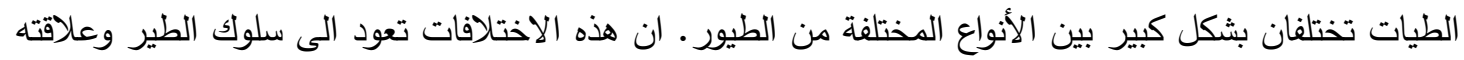

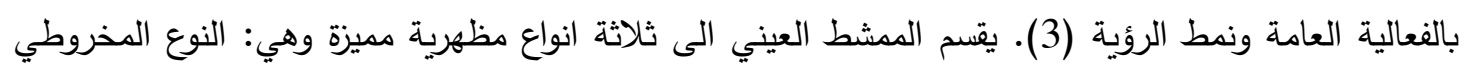
Conical type المروحي (النصلي) Vaned type الذي يتألف من عمود مسطح مركزي تتشأ منه الطيات العمودية كما في في وني النعامة Ostrich وطائر الرية Rhea، بينما يكون في بقية الطيور من النوع المطوي Pleated type، إذ تكون منائ طياته شبيهة بآلة الاوكورديون الموسيقية (3، 4). 
ان التركيب النسجي للمشط العيني في الطيور يتكون اساساً من عدد كبير من الاوعية الدموية وثلاثة انواع من الخلايا، هي الخلايا البطانية Endothelial cells، والخلايا الصباغية (الخلايا الميلانية Pigmented cells (Melanocytes

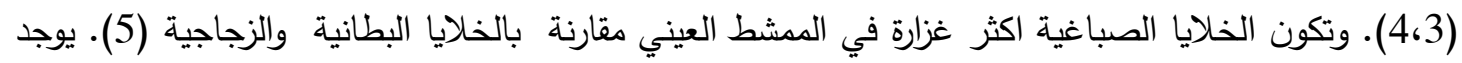

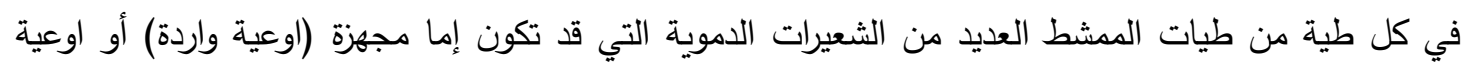
تصريف (اوعية ناقلة)، ولا يمكن التمييز بينها فيما اذا كانت شريينات او وريدات نتيجة عدم وجود فروق تركيبية

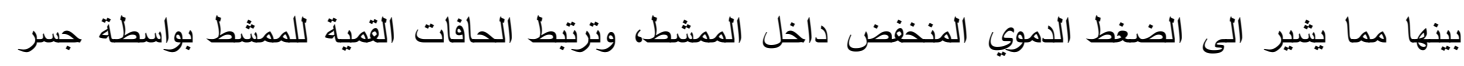

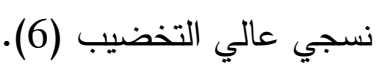

تكون وظيفة المشط غير معروفة بشكل كامل، الا ان العديد من الدراسات النسجية للمشط اكدت انه تركيب وعائي جداً ووظيفته الرئيسة هي تغذية الثبكية الداخلية اللاوعائية في الطيور وهذا الدور الانية الغذائي

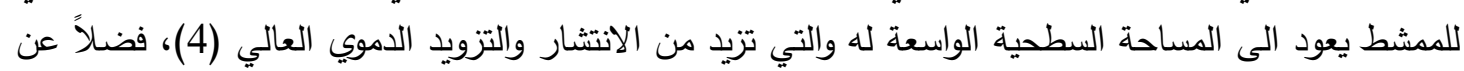

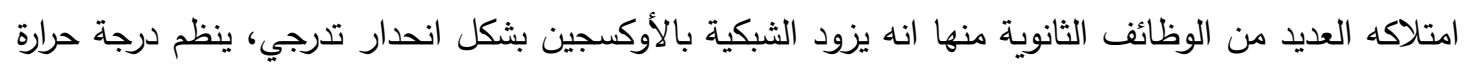

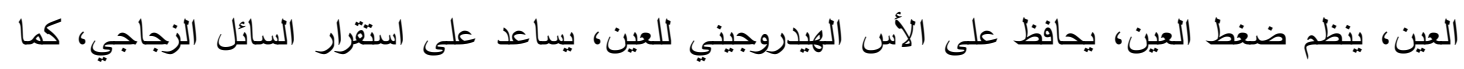

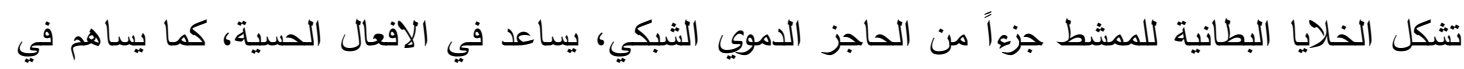

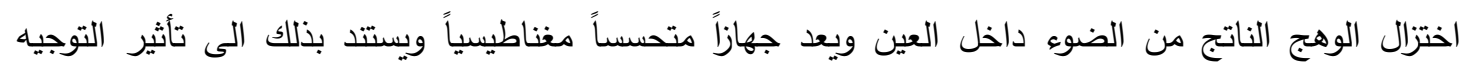
المغناطيسي للأرض (4، النج (7).

هدفت هذه الدراسة الى معرفة التركيب النسجي لمشط العين في ثلاثة انواع من الطيور مختلفة

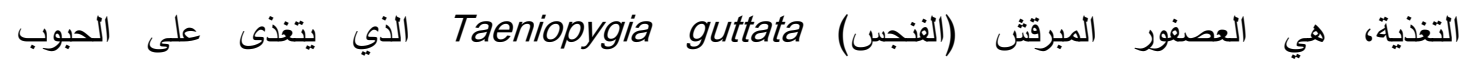
والزرزور الثائع Sturnus vulgaris (grainivorous) (Omnivorous والباشق الذي يسمى محلياً باشق العصافير Accipiter nisus (من آكلات اللحوم .(Carnivorous

\section{Materials and Methods المواد وطرائق العمل}

تطلبت الدراسة الحالية لممشط العين للطيور الثلاثة، جمع طيور بالغة اختيرت بحيث تكون سليمة من الامراض والعيوب، إذ تم الحصول عليها من سوق الطيور في مدينة الموصل وبواقع (5-10) طيور لكل نوع.

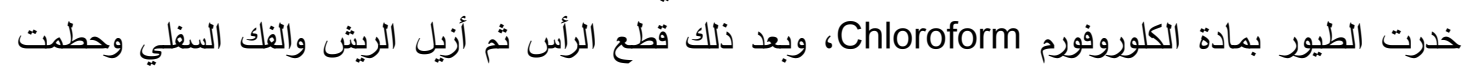

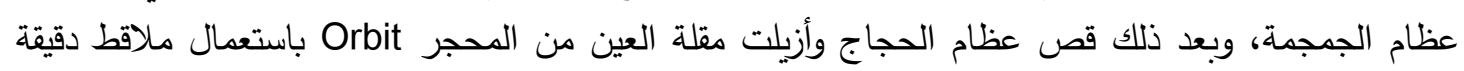
وأعقب ذلك قطع العضلات المرتبطة بها مع مراعاة الاحتفاظ بجزء من العصب البط البصري.

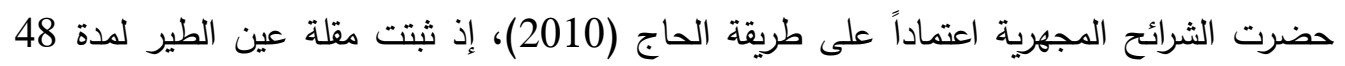

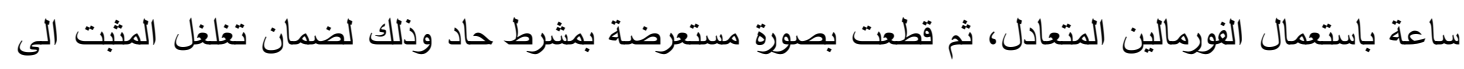
داخل النسيج ولتحاشي تمزق الشبكية في حالة قطع العينات، بعد ذلك غسلت العينات بالماء الجاري لمدة 5 ساعات، وبدأ انكاز المقاطع بسلسلة من التراكيز التصاعدية من الكحول الأثيلي بدءاً من تركيز

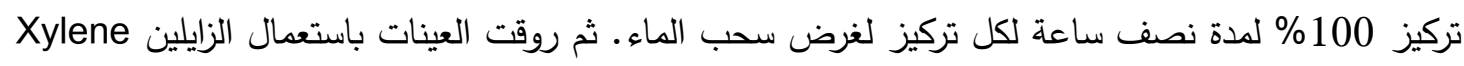

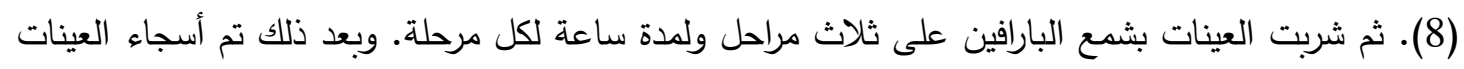

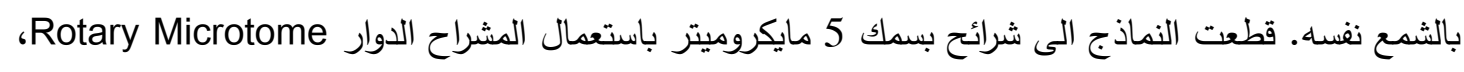

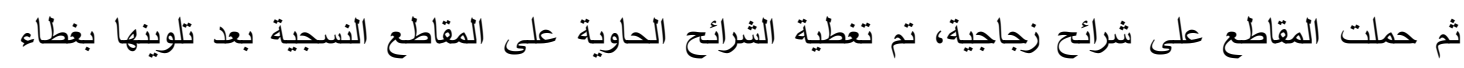

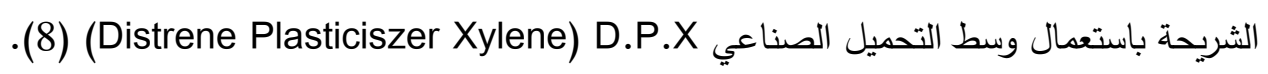


وقد استعملت ملونات نسجية عامة وملونات خاصة بالكيمياء النسجية لتلوين المقاطع، اذ استعمل ملون

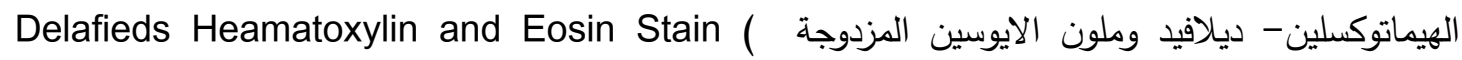

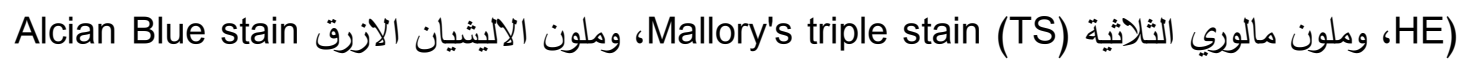

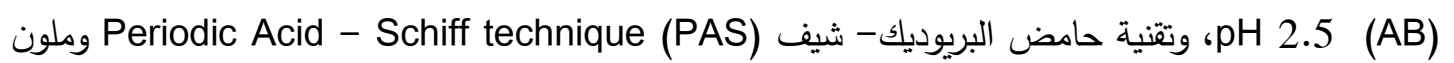

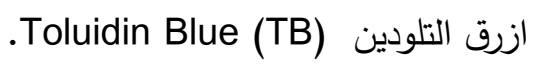

\section{Result النتائج}

ظهر المشط العيني بشكل تركيب اسفنجي في الطيور الثلاثة وهو تركيب عالي التوعية ينشأ من البقعة العمياء فوق العصب البصري. ويتكون من صفائح عديدة مطوية تبرز الى داخل السائل الزجاجي الا انها

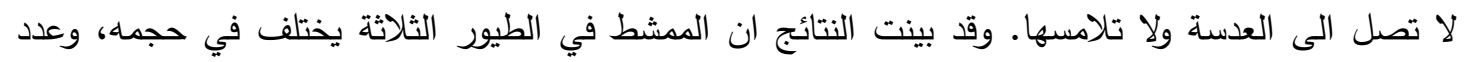
طياته وسعتها.

ففي الباشق ظهر المشط العيني من النوع المطوي وقد بلغت عدد طياته (17) طية وتُكون هذه الطيات تركيباً مشابهاً لألة الاكورديون الموسيقية (الصورة:1)، تتصل طيات المشط العشئ العيني بالبقعة العمياء

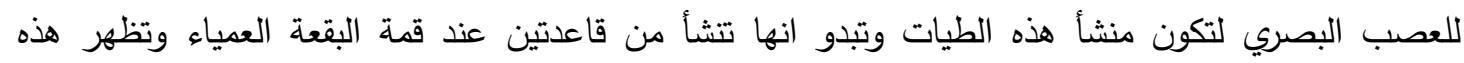
القواعد قادمة من طبقة المشيمية وتخترق العصب البصري عند هذه البقعة، اولى هذه القواعد تكون بشكل وعاء لـاء

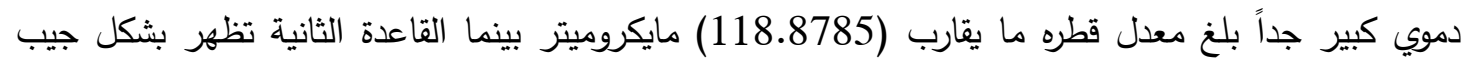
دموي واسع جداً وغني بالأوعية الدموية وتتصل هذه القواعد بغلاف البقعة العمياء (الصورة:2)، بعد ذلك يظهر

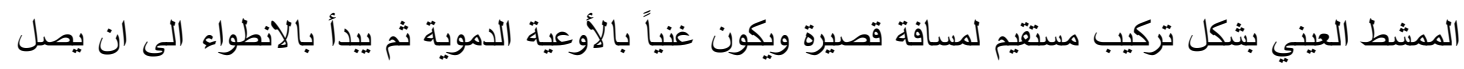

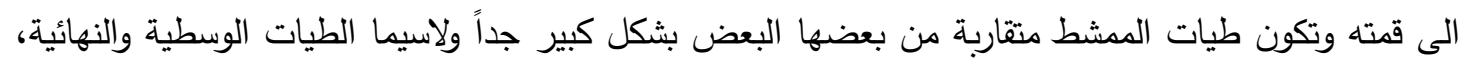

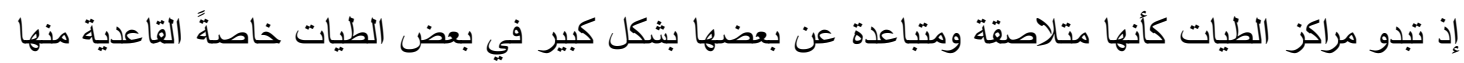

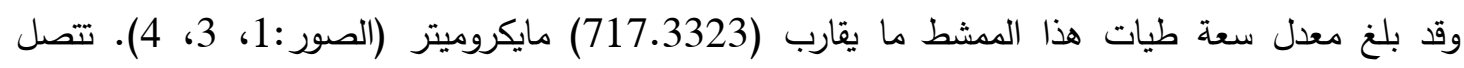
الطيات النهائية بتركيب يعرف بالجسر وهو عبارة عن كتلة من نسيج ضام ذي تخضي تخيب عالٍ جداً، ويكون هذا الجسر كبيراً نسبياً وذا شكل غير منتظم ويتكون هذا الجسر من حافة عليا وسفلى وسداة وسطية تحوي السداة

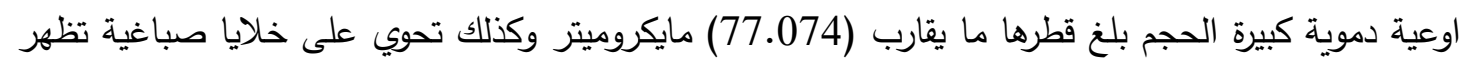

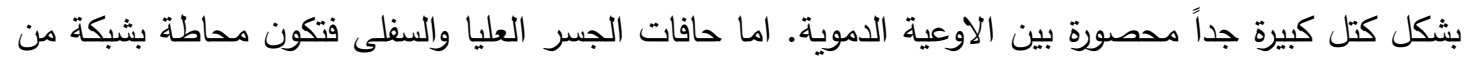
الاوعية الدموية صغيرة الحجم نسبياً بلغ معدل قطرها ما يقارب (37.8826) مايكروميتر محاطة بالكامل بالخلايا الصباغية (الصورتان:1، 4). تتكون كل طية من الناحية النسجية من شبكة كثيفة من الثعيرات الدموية الصغيرة والمتوسطة الحجم بلغ معدل قطر الاوعية الصغيرة ما يقارب (17.0011) مايكروميتر بينما بلخ معدل قطر الاوعية الدموية متوسطة الحجم ما يقارب (42.696) مايكروميتر وينتشر بين هذه الاوعية عدد قليل من منارئ الاوعية الدموية كبيرة الحجم وقد يكون عددها ثلاثة الى خمسة في كل طية يتوسطها وعاء دموي كبير جداً اكبر

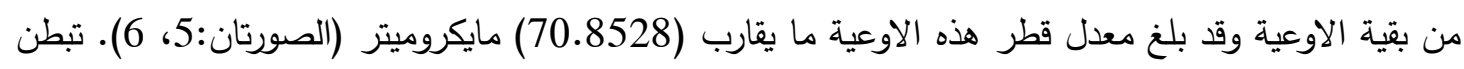

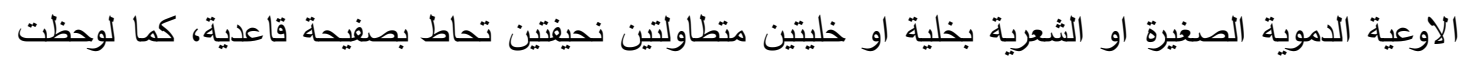

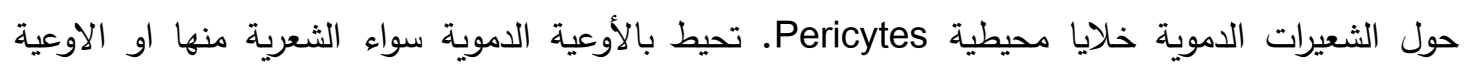
المتوسطة او الكبيرة خلايا صباغية غنية بالجسيمات الميلانية وتبدو هذه الخلايا وقد احاطت بمعظم الاوعية بالاتية

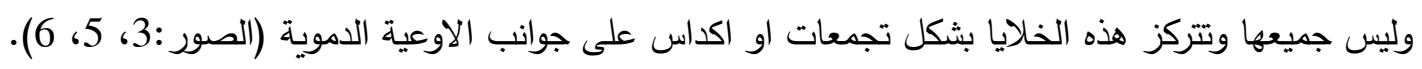


امير محمود طاه الحمداني \& حامد حسان حامد الاعرجي

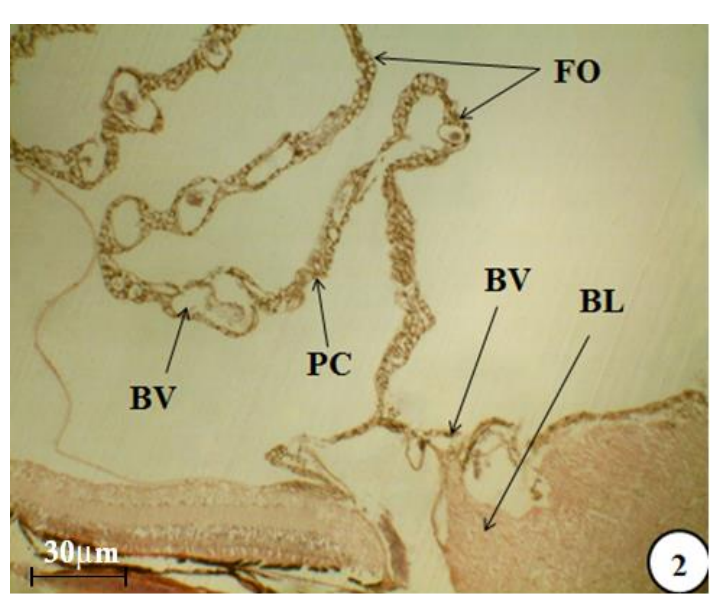

(الصورة2): مقطع طولي في مركز كرة العين يوضح منشأ

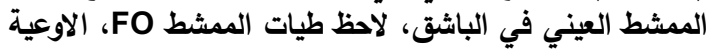

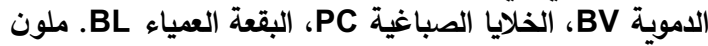

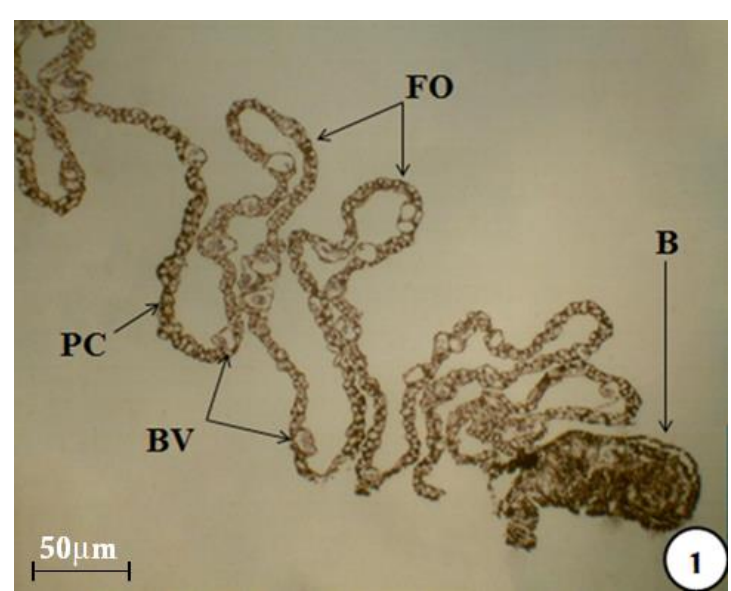

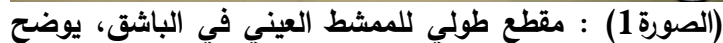

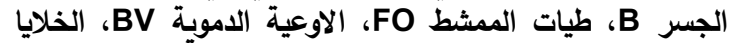

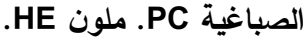

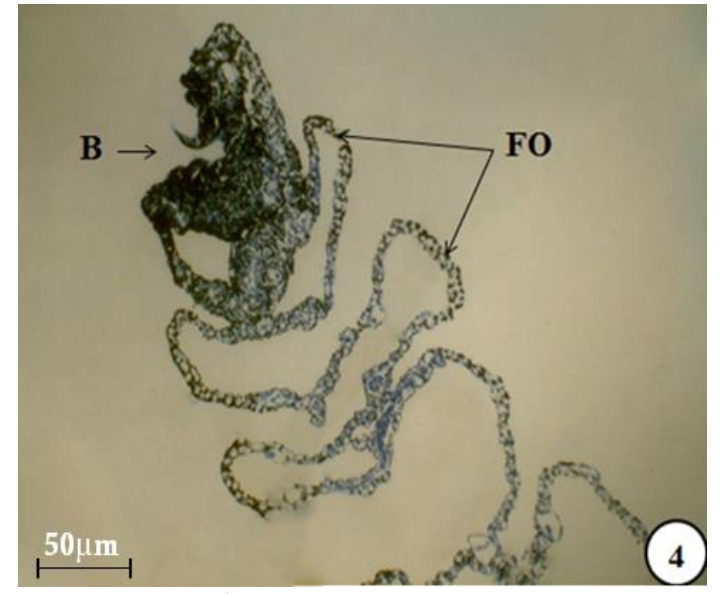

(الصورة4): مقطع طولي للمشط العيني في الباشق، يوضح

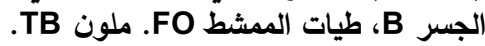

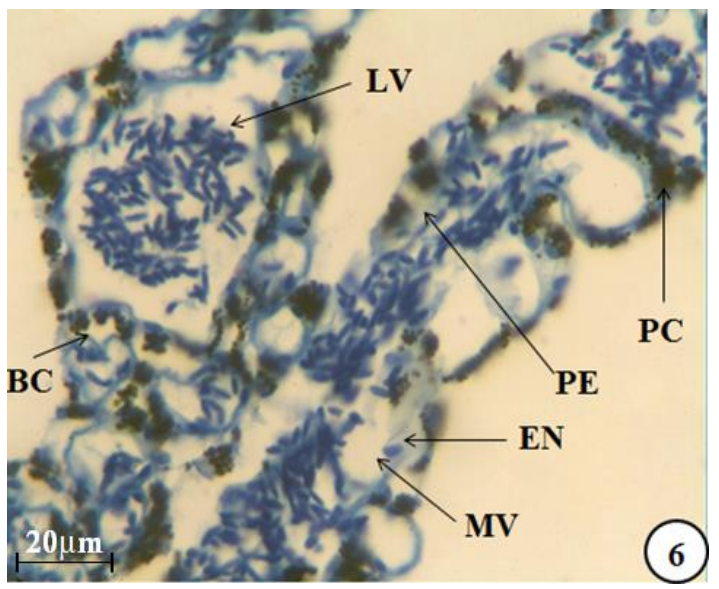

(الصورة6): مقطع مكبر في احدى طيات المشط العيني في الباشق توضح التراكيب التفصلية لها، لاحظ الاوعية الألموية

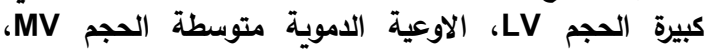

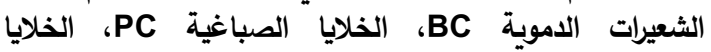
المحيطية PE، الخلايا البطانية EN. ملون TB.

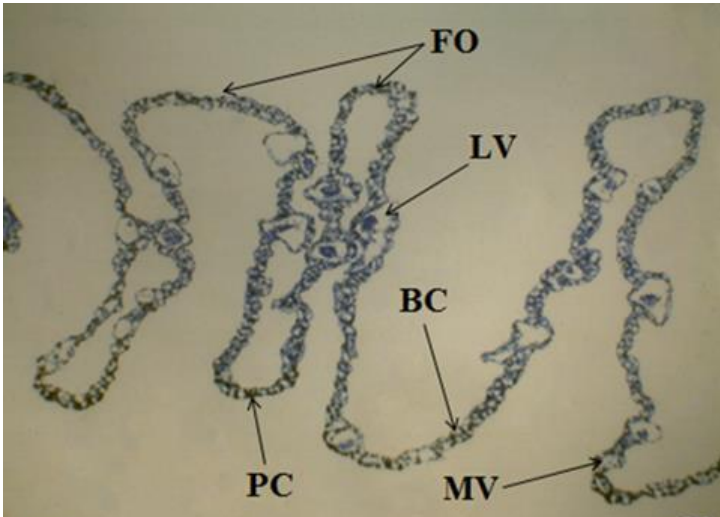

$50 \mu \mathrm{m}$

(3)

(الصورة3): مقطع طولي في المشط العيني في الباشق، يوضح التئح

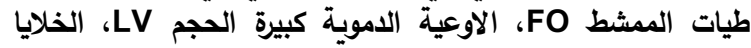

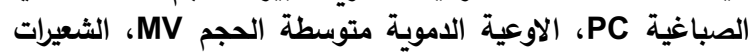

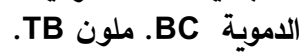

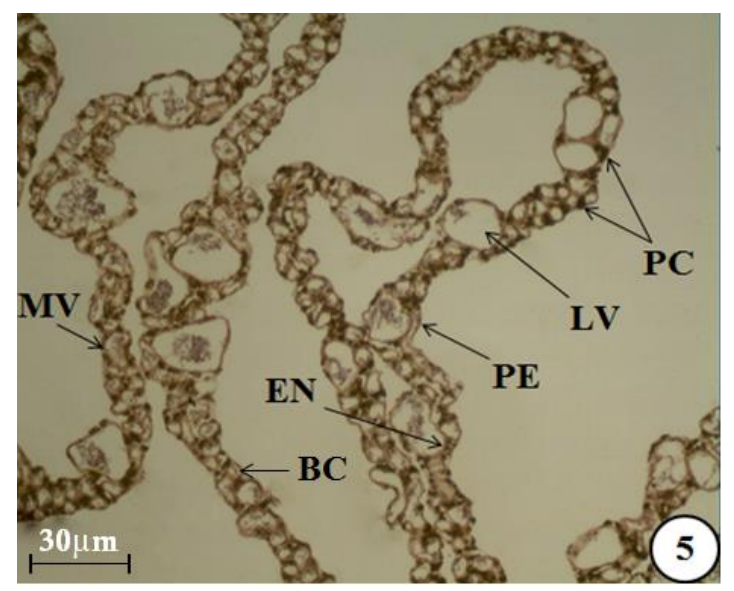

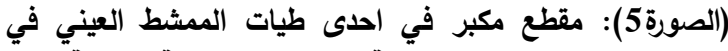
الباشق توضح التراكيب التفضلية لها، لاحظ الاوعية الدموية كبيرة

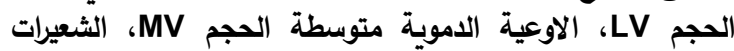

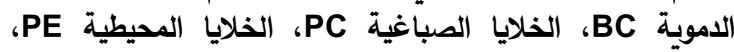
الخلايًا البطانية EN. ملون PAS. 
اما في الزرزور فقد ظهر المشط العيني مشابهاً في تركيبه الاساسي لنظيره في الباشق بصورة عامة،

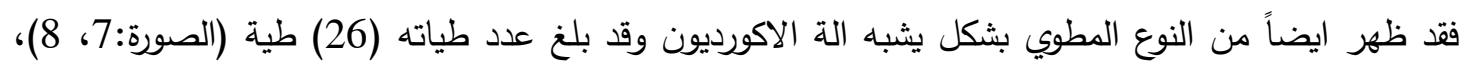

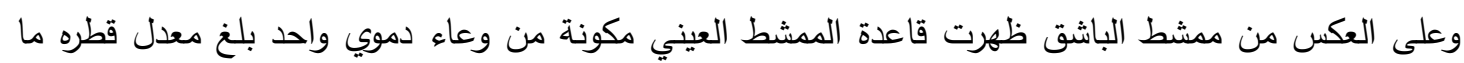

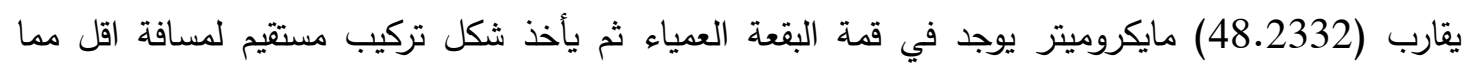

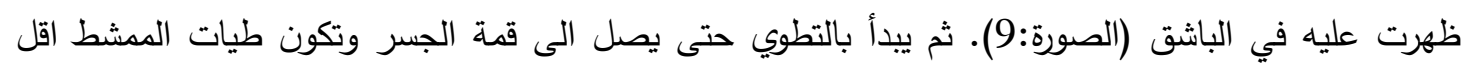
عرضاً من نظيره في الباشق من بدايته الى قمته وقد بلغ معدل عرض هذه الطيات ما يقارب (597.1013)

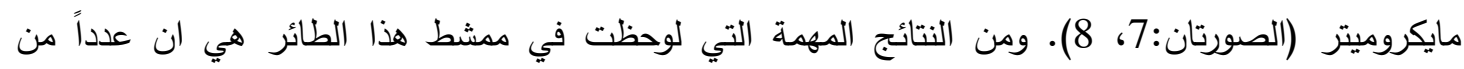

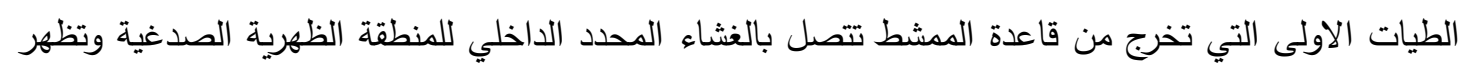
اوعيته الدموية مخترقة للغشاء بشكل واضح ثم بعد ذلك تصبح الطيات حرة وتبدأ بالتطوي (الصورة:9). يظهر

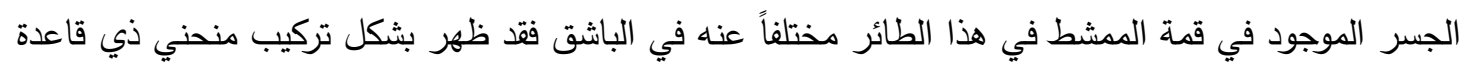

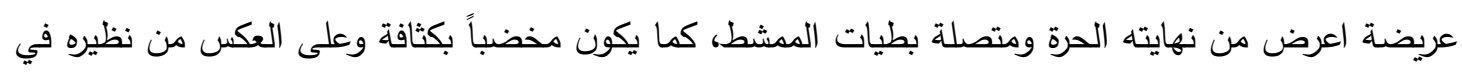

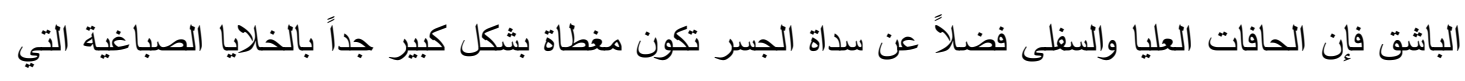

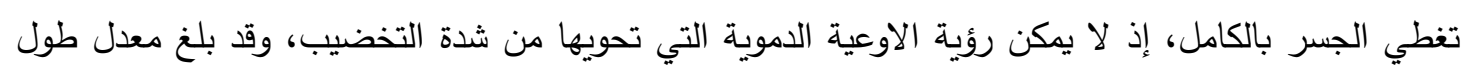
الجسر ما يقارب (418.7752) مايكروميتر (الصورة:10). اما التركيب النسجي لطيات المشط في فئ هذا الطائر

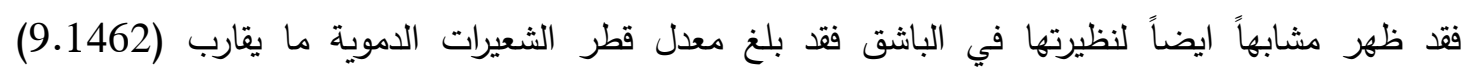

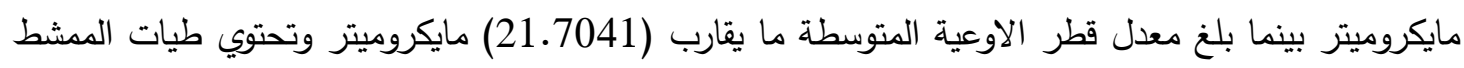
في هذا الطائر ثلاثة اوعية دموية كبيرة، اذ ظهر احد الاوعية كبير ويتوسط الطيات وقد بلغ معدل قطر هذه مانه الاوعية ما يقارب (36.8268) (الصور:7، 8، 11، 12، 12، مايكروميتر . تبطن الاوعية الدموية ايضاً بخلايا

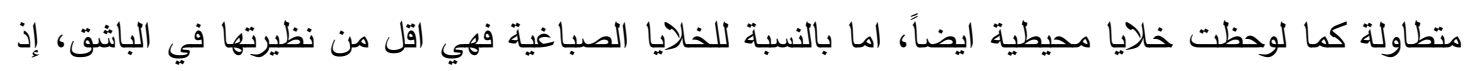
تكون تكتلات هذه الخلايا اقل كما توجد بعض الشعيرات الدموية غير محاطة بخلايا صباغية (الصورتان:11،

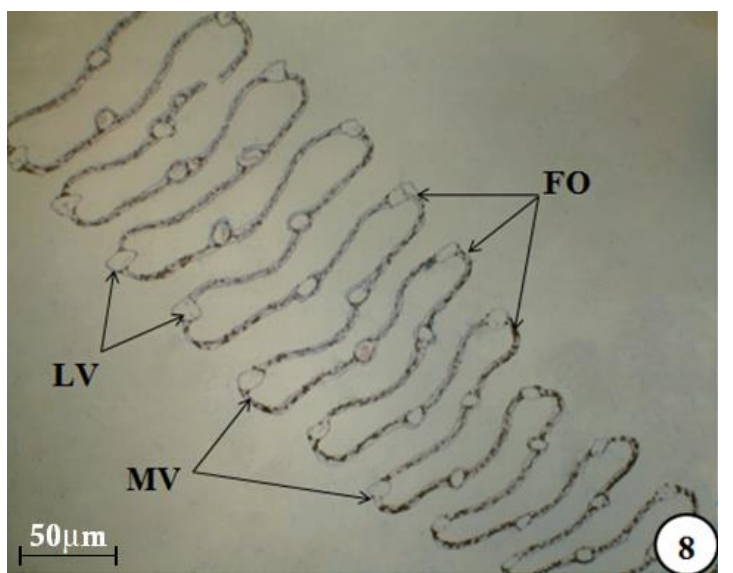

(الصورة8): مقطع طولي للمشط العيني في الزرزور ، يوضح

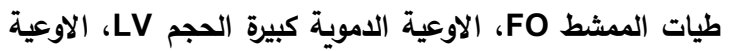
الاموية متوسطة الحجم MV. ملون AB.

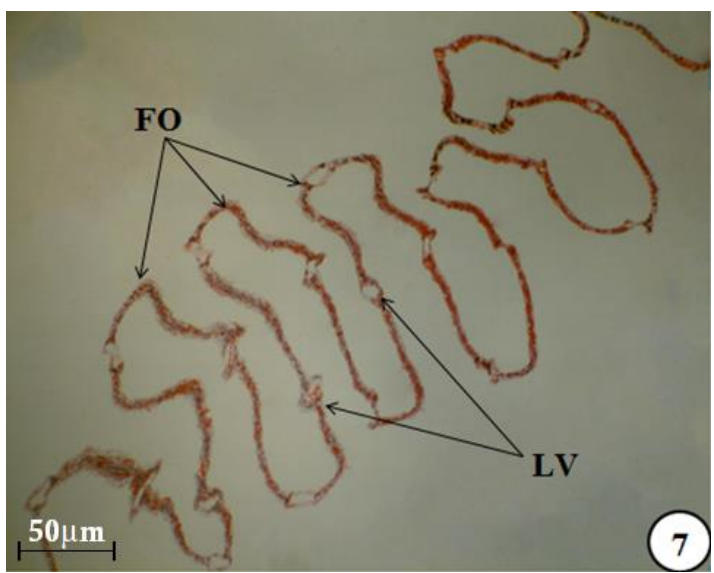

(الصورة7): مقطع طولي للمشط العيني في الزرزور، يوضح

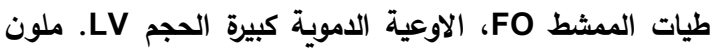
.TS 


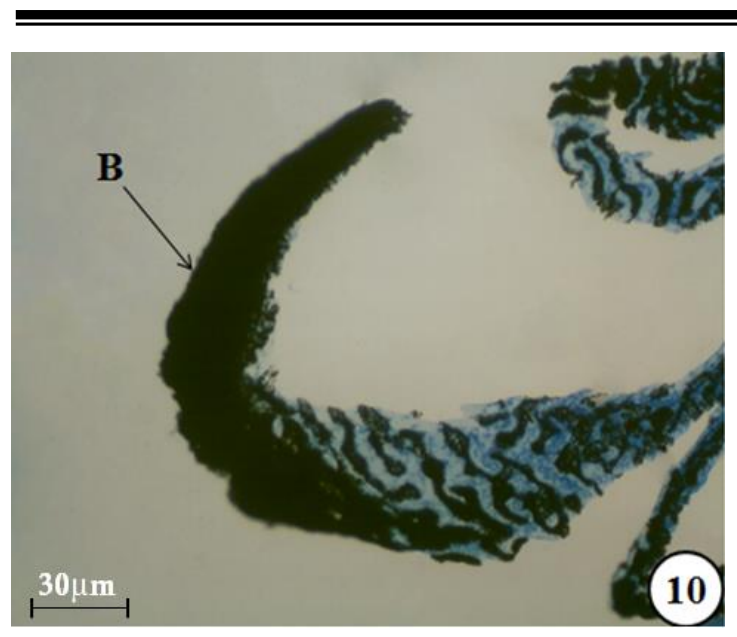

(الصورة10): مقطع طولي مكبر في منطقة الجسر B لممشط عين الزرزور . ملون TB.

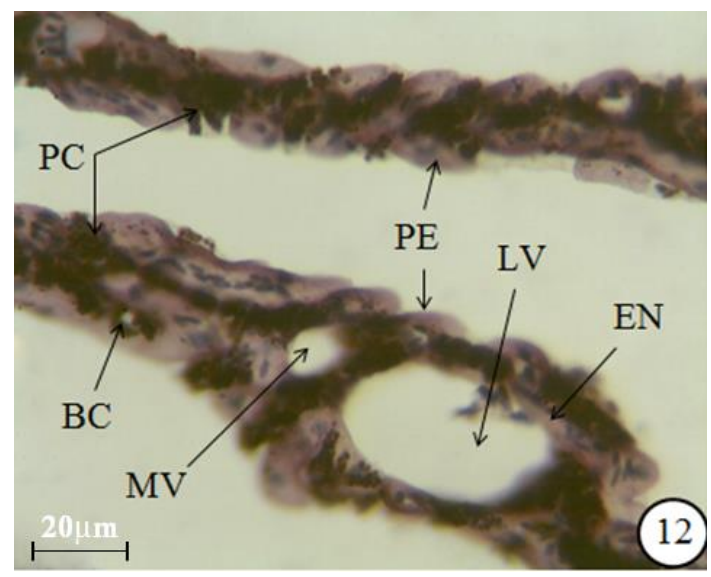

(الصورة12): مقطع مكبر في إحدى طيات الممشط العيني في الزرزور توضح التراكيب التفصلية لها، لاحظ الاوعية الدموية

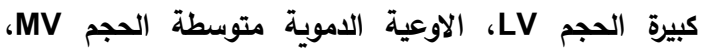
الشعيرات الدموية BC PC الخلايا الصباغية PC، الخلايا المحيطية PE، الخلايا البطانية EN. ملون PAS.

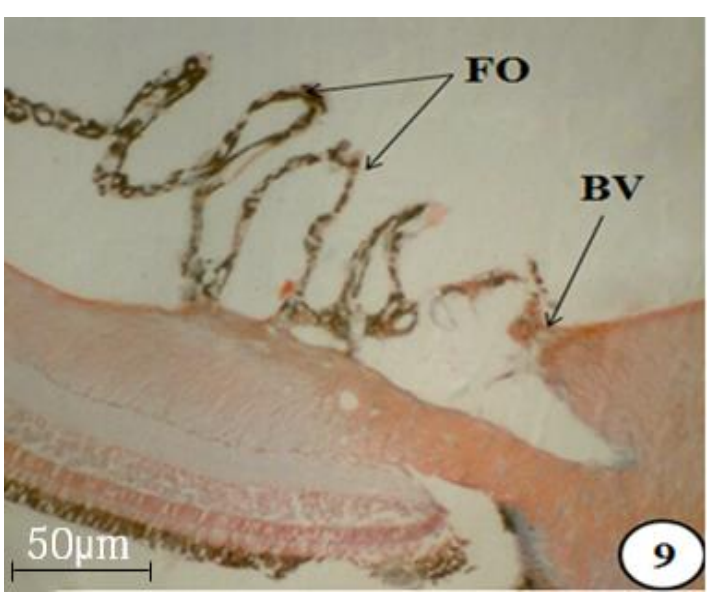

(الصورة9): مقطع مستعرض في الشبكية ومنطقة الممشط العيني في الزرزور، يوضح طيات المشط مS FO، الاوعية

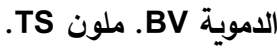

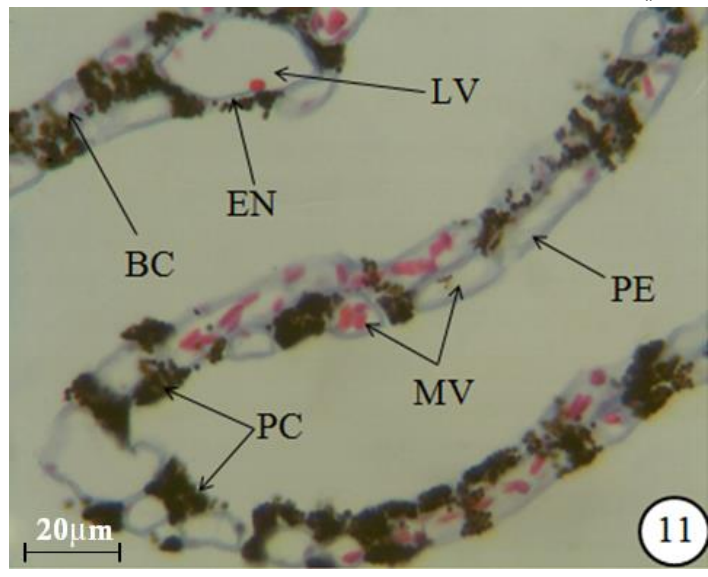

(الصورة 11): مقطع مكبر في إحدى طيات الممشط العيني في الزرزور توضح التراكيب التفصلية لها، لاحظ الاوعية الدموية اهية كبيرة الحجم LV، الاوعية الدموية متوسطة الحجم MV،

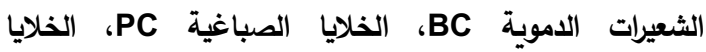
المحيطية PE، الخلايا البطانية EN. ملون TS.

اما في العصفور المبرقش فقد ظهر المشط مشابهاً لما ظهر عليه في النوعين السابقين، اذ ظهر

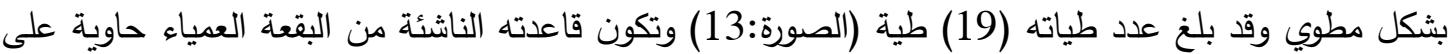
ثلاثة اوعية دموية بلغ معدل قطرها ما يقارب (32.8266) مايكروميتر كما اختلف الممشط عن من النية النوعين

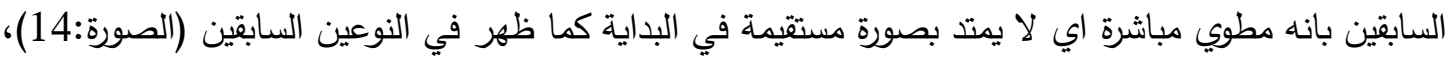

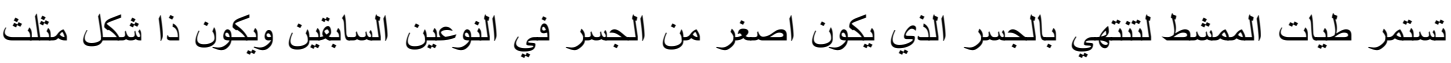
تقريباً وتتصل طية الممشط الاخيرة بمنتصف الجسر وقد بلغ معدل طول الجسر ما يقارب (154.7459)

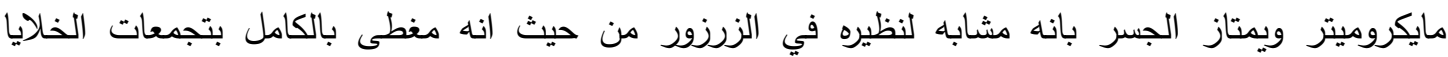

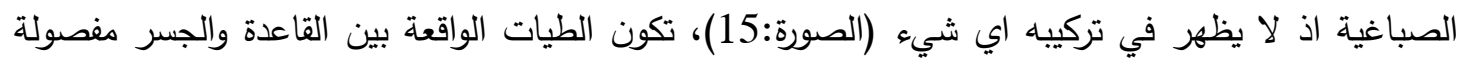

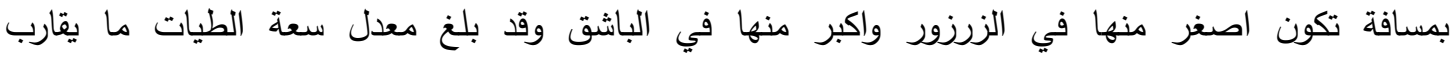

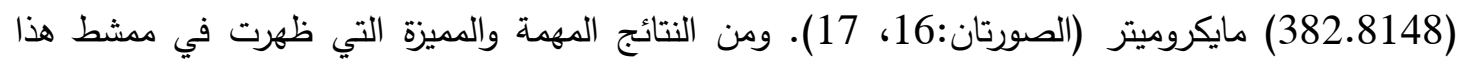

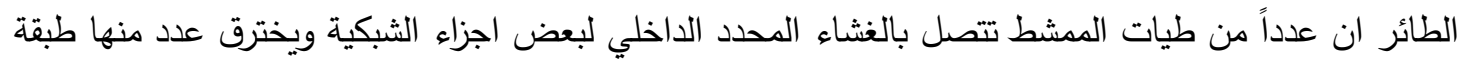
الالياف العصبية وكذلك طبقة الخلايا العقدية وقد يصل الى الطبقة الضفيرية الداخلية وتكون بتماس مع الطبقة 
النووية الداخلية وتزداد طبقة الالياف العصبية حول اوعية المشط التي اخترقت هذه الطبقة وقد وجد في إحدى التيك

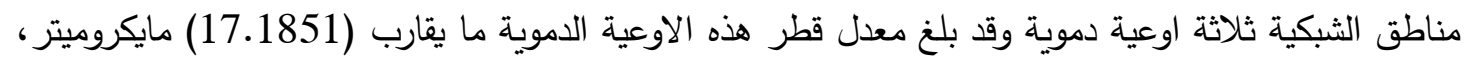

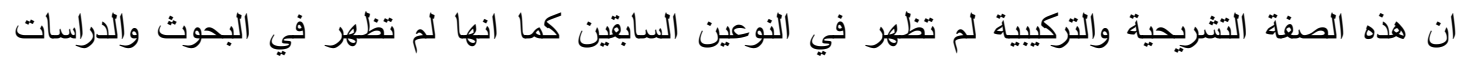

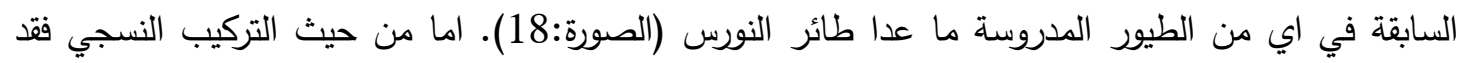
ظهرت الطيات مشابهة للنوعين السابقين وقد بلغ معدل قطر الشعيرات الاموية ما يقارب (18.4134) مائ من مايكروميتر بينما بلغ معدل قطر الاوعية الدموية المتوسطة ما يقارب (20.9747) مايكروميتر ، اما بالنسبة للأوعية الدموية

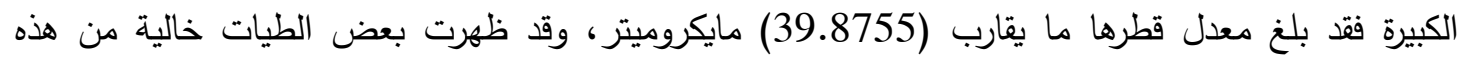

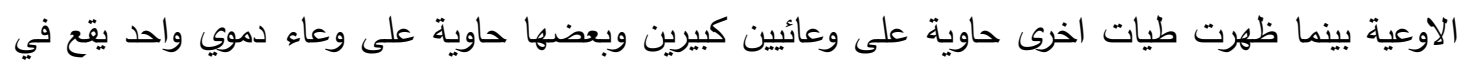

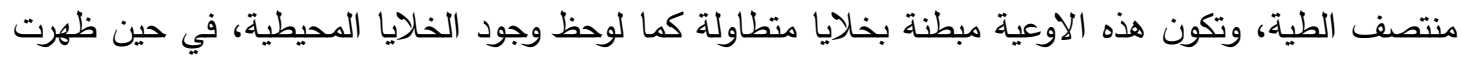

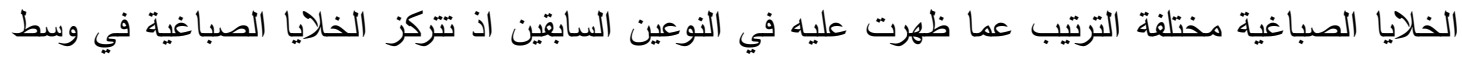

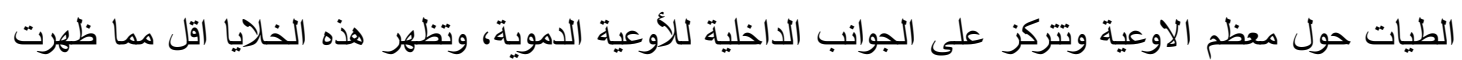

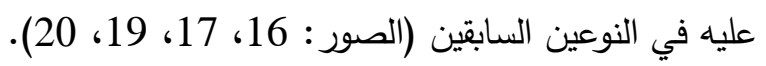

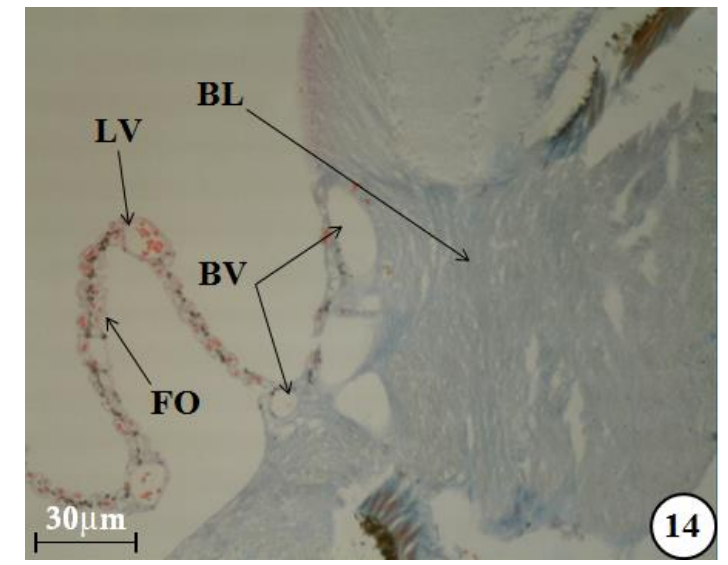

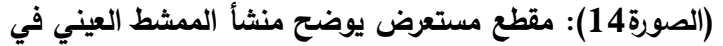

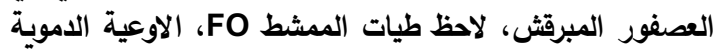

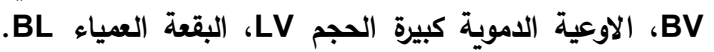

ملون TS. - مل

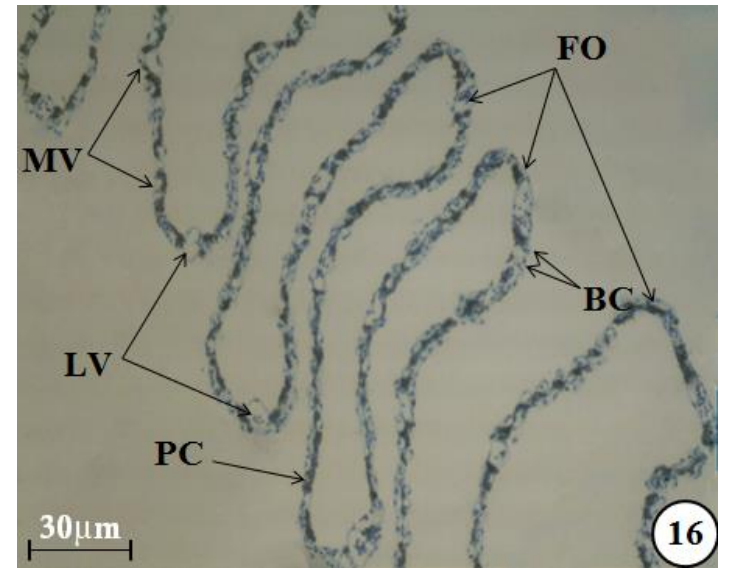

(الصورة16): مقطع طولي في الممشط العيني في العصفور

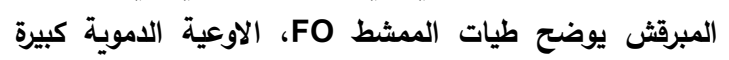
الحجم LV، الخلايا الصباغية PC، الاوعية الدموية متوسطة الحجم MV، الشعيرات الدموية الفياعم BV. ملون TB.

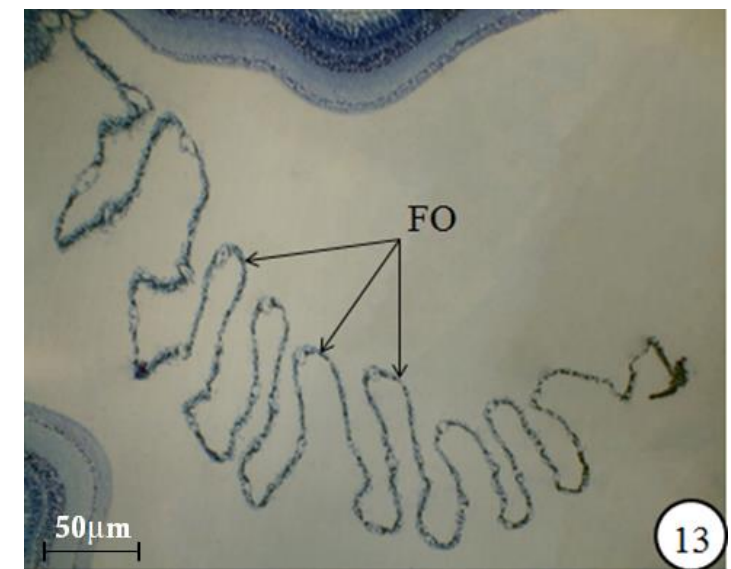

(الصورة13): مقطع طولي للممشط العيني في العصفور

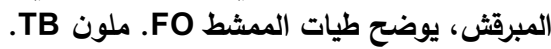

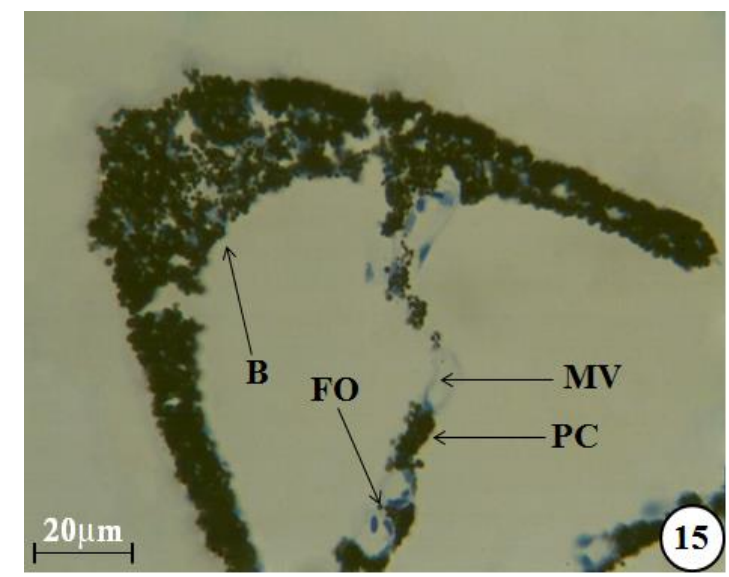

(الصورة15): مقطع طولي للممشط العيني في العصفور

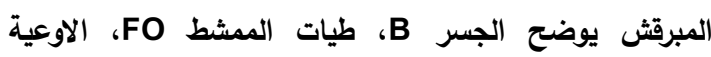
الاموية متوسطة الحجم MV، الخلايا الصباغية PC. .TB 


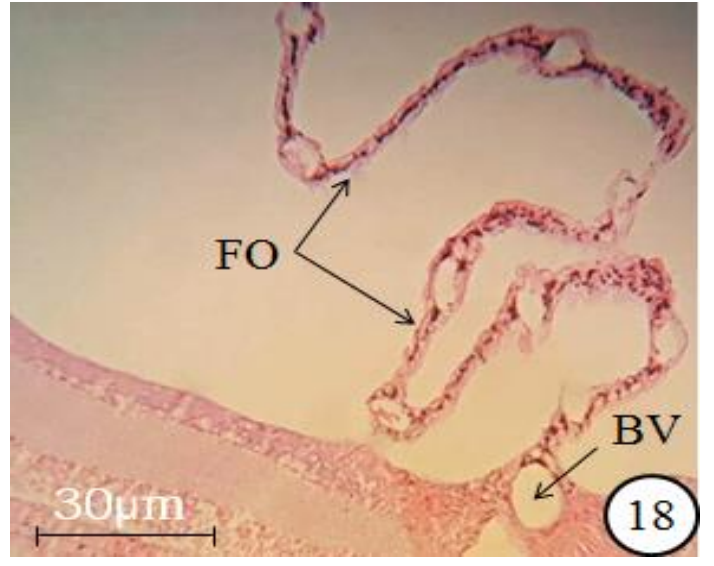

(الصورة18): مقطع مستعرض في الثبكية ومنطقة المششط

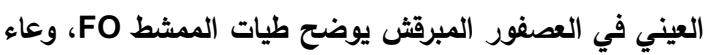

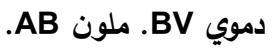

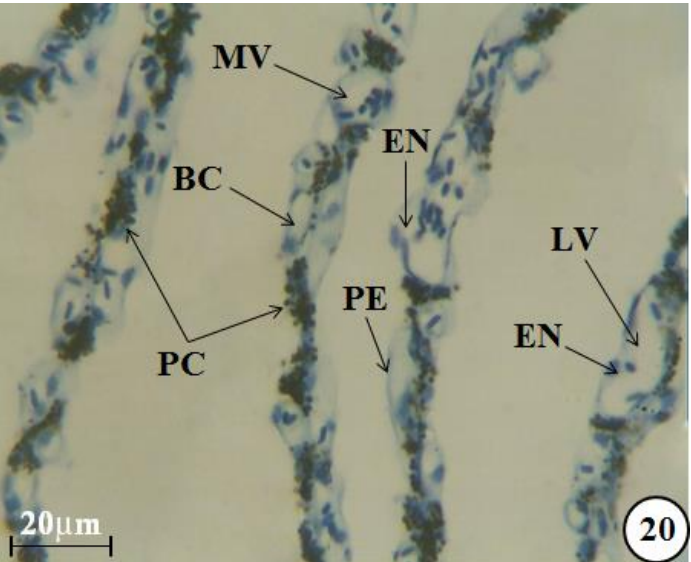

(الصورة20): مقطع مكبر في إحدى طيات المشط العيني في العصفور المبرقش توضح التراكيب التفصلية لها، لاحظ الاوعية

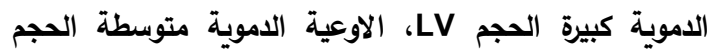

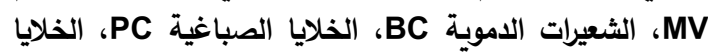

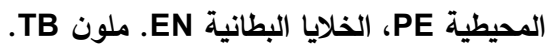

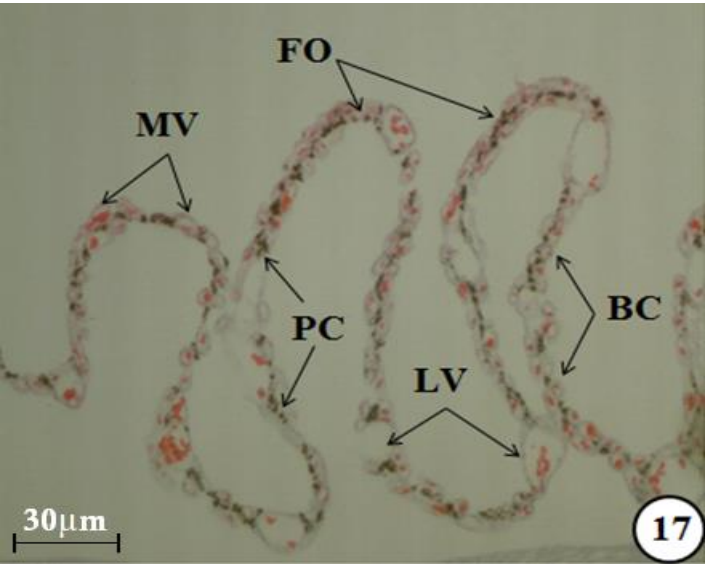

(الصورة17): مقطع في إحدى طيات المشط العيني FO في

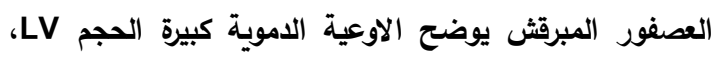

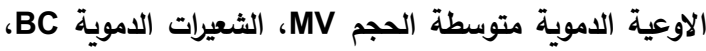
الخلايا الصباغية PC، الخلايا المحيطية PE، الخلايا البطانية

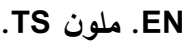

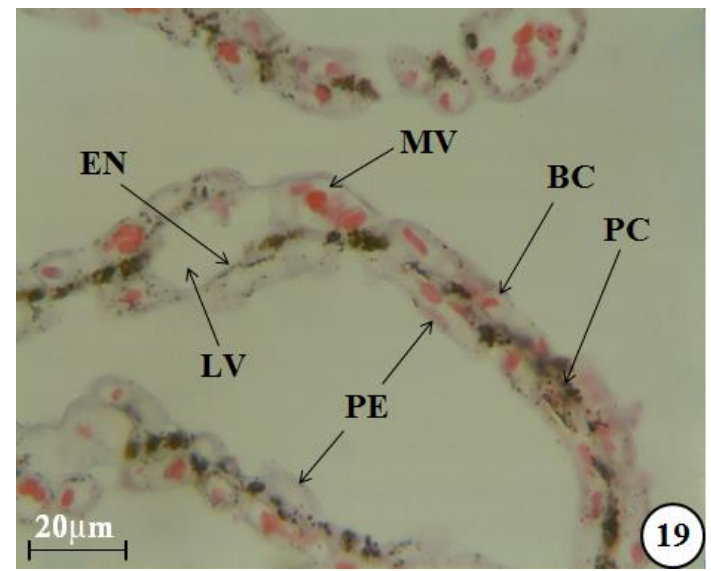

(الصورة19): مقطع مكبر في إحلى طيات المشط العيني في

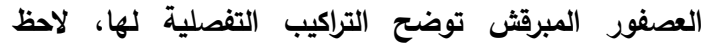
الاوعية الاموية كبيرة الحجم LV الاعتوفية الاوعية الاموية متوسطة

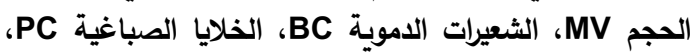

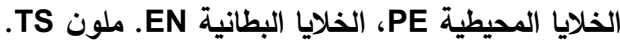

\section{Discussion المناقثة}

المشط العيني في طيور الدراسة الثلاثة على شكل تركيب اسفنجي اسود اللون من النوع المطوي يشبه آلة الاكورديون الموسيقية، وان للمشط العيني في الطيور الثلاثة خواصاً نوعية مثل حجماه، تعقيد تركيبه ودرجة الثانة

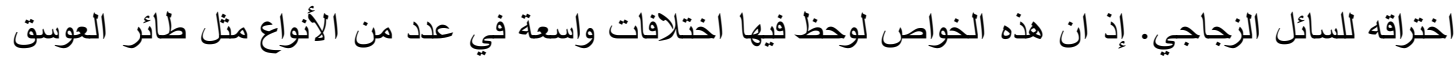

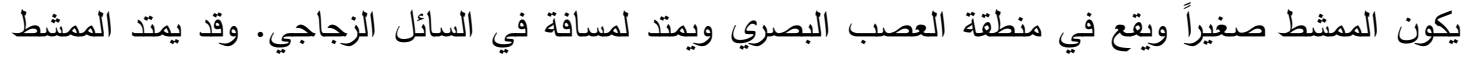

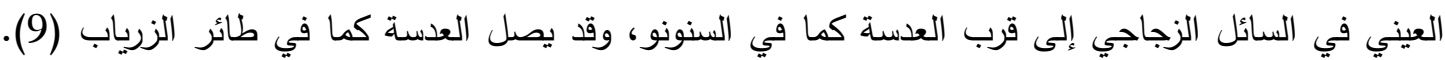

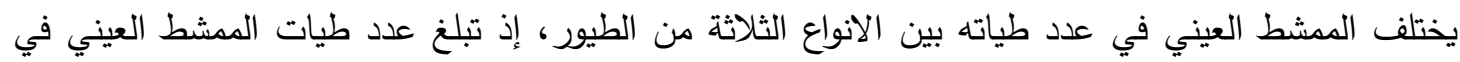

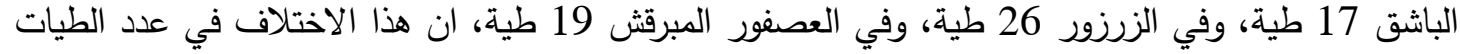
ظهر في الأنواع المختلفة من الطيور، اذ ظهر في طائر القطا العراقي 20 طية (10)، وفي مرفي مرعة البر 12 طية (11) وفي البيغاء المتيمة 9 طيات وفي دجاج غينيا 16 طية (12)، وفي العوسق 17 طية (13)، وفي 
الخضيري 10-12 طية (14)، وفي النورس 18-21 طية (5)، وفي بومة الحظيرة 7-8 طيات (1)، وفي

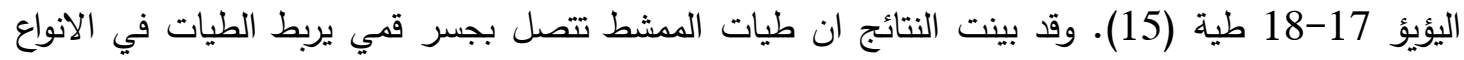

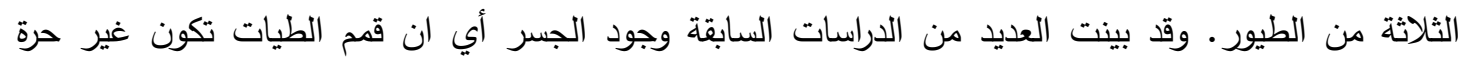

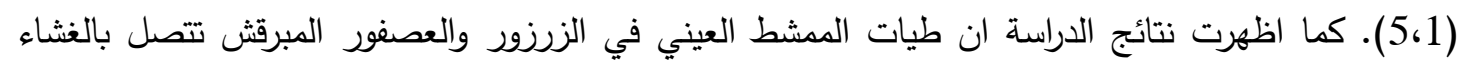

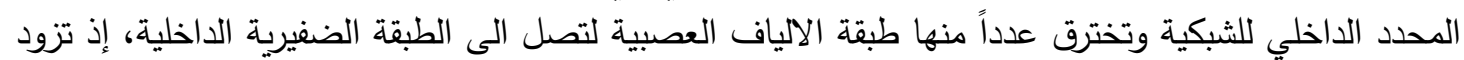

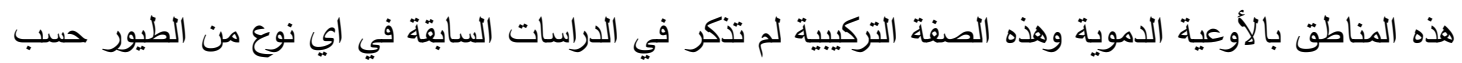
اطلاعنا ماعدا طائر النورس (12)، إن اختراق هذه الأوعية لطبقة الألياف العصبية ربما يدل على فلى قوة التجهز

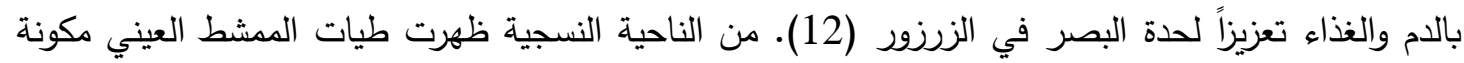

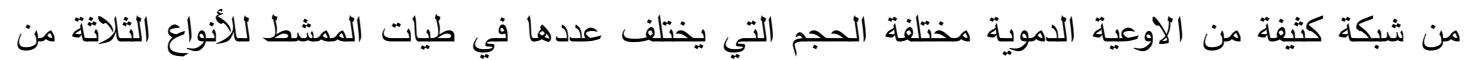

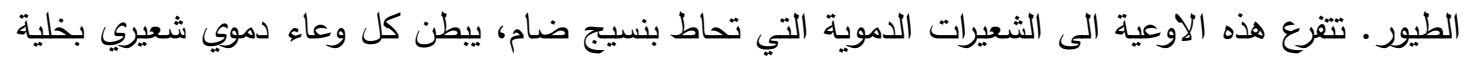

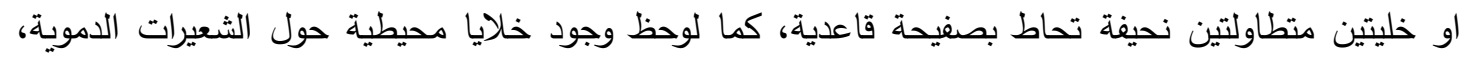

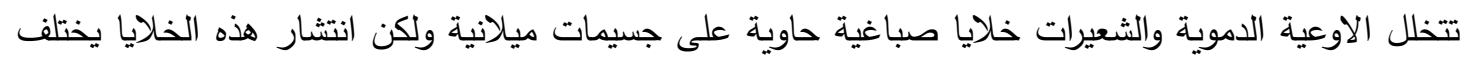

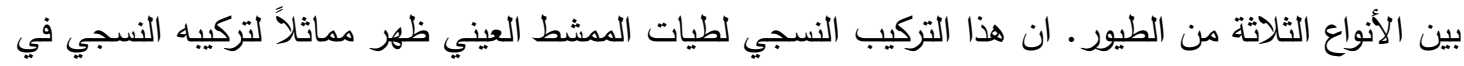

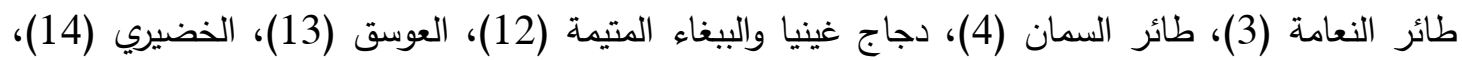
النورس (5) وبومة الحظيرة (1).

تؤكد الدراسة الحالية ان للمشط العيني دوراً مهماً في تزويد شبكية عين الطيور بالأوكسجين والغذاء

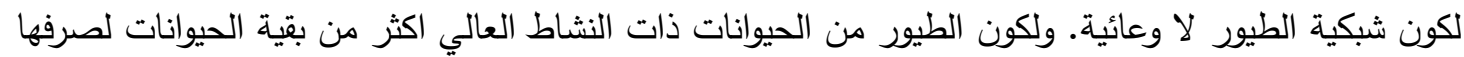

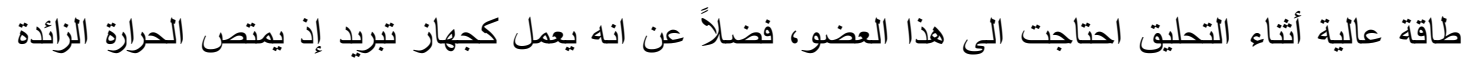

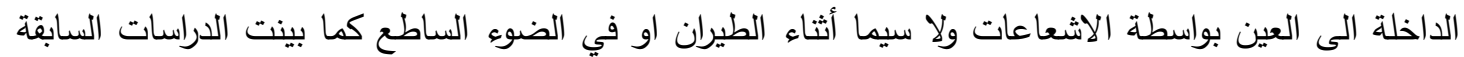

ونستنتج من الدراسة الحالية الاختلاف في الصفات التشريحية ونظام التوعية بين الانواع الثلاثة من طيور الدراسة.

\section{References المصادر}

1) Yilmaz, B.; Korkmaz, D.; Alan, A.; Demircioğlu, İ.; Akbulut, Y and Oto C., Kafkas Univ Vet Fak Derg., 23 (6): 973-979. (2017).

2) Gallego, M. L. V., Ph.D. Dissertation universität münchen. (2015).

3) Kiama, S.G.; Maina, J.N.; Bhattacharjee, J.; Mwangi, D.K.; Macharia, R.G. and Weyrauch, K.D., Ann Anat., 188: 519-28. (2006).

4) Orhan, I. Ö.; Ekim, O. and Bayeaktaroglu, A. G., Ank Üniv Vet Fak Derg., 58: 5-10 (2011).

5) İnce, N.G.; Onuk, B.; Kabak, Y.B.; Alan, A and Kabak M., Micr. Res. Tech., 80: 787-792 (2017).

6) Braekevelt, C. R., Tissue and Cell., 2:157-165. (1998).

7) Jones, M.P.; Pierce, K. E. and Ward, D., J. Exo. Pet. Med.,16 (2):69-87 (2007).

8) ALHajj, H. A.,"optical microscopy preparations" $1^{\text {st }}$ Ed. Aman- Jourdan (2010).

9) Sillman, A. J., Visi. Res., 9: 1063-1077. (1979).

10) Abed, A. A.; Ahmed, D. F. and Hamodi, H. M., Tikr. J. Pur. Scie., 15 (2): 246260 (2010).

11) Abd, A. A. and Abd Al Majeed, S. A., J. Scie Rafi., 21(4):1-26 (2010).

12) Al-hamadany, A. M. T. A. Ph.D. Dissertation. College of Education. Mosul University (2012).

13) Gali, M. A. and Abid, Sh. A., Bagh. J. Scie.,12(1):8-12 (2015).

14) Ghazi, T. Sh. and Ghali, M. A., Inter. J. Scie. Tech., 12(1):56-59 (2017).

15) Demirkan, A. C.; Türkmenoglu, İ.; demirkan, İ.; akosman, M. S and akalan, M. A., Koca. Vet J., 11(3): 1-7 (2018).

16) Salah El-Din, E. Y and Dakrory, A. I.., Egypt Journal. 37(1): 14-20 (2016). 